\title{
Analysis of viral and cellular parameters which affect the fusion process of influenza viruses
}

A.T.C. Barbosa, M.O. Luiz,

N.P. Gusmão and J.N.S.S. Couceiro
Departamento de Virologia, Instituto de Microbiologia Prof. Paulo de Góes, Universidade Federal do Rio de Janeiro, Rio de Janeiro, RJ, Brasil

\section{Correspondence}

J.N.S.S. Couceiro

Departamento de Virologia

Instituto de Microbiologia

Prof. Paulo de Góes

CCS, UFRJ, Bloco I

21941-590 Rio de Janeiro, RJ

Brasil

Research supported by CNPq,

Finep and FUJB/UFRJ.

....................

Received August 19, 1996

Accepted September 17, 1997

\begin{abstract}
In the present investigation we studied the fusogenic process developed by influenza A, B and C viruses on cell surfaces and different factors associated with virus and cell membrane structures. The biological activity of purified virus strains was evaluated in hemagglutination, sialidase and fusion assays. Hemolysis by influenza A, B and $\mathrm{C}$ viruses ranging from 77.4 to $97.2 \%$, from 20.0 to $65.0 \%$, from 0.2 to $93.7 \%$ and from 9.0 to $76.1 \%$ was observed when human, chicken, rabbit and monkey erythrocytes, respectively, were tested at $\mathrm{pH}$ 5.5. At this $\mathrm{pH}$, low hemolysis indexes for influenza $\mathrm{A}, \mathrm{B}$ and $\mathrm{C}$ viruses were observed if horse erythrocytes were used as target cells for the fusion process, which could be explained by an inefficient receptor binding activity of influenza on $\mathrm{N}$-glycolyl sialic acids. Differences in hemagglutinin receptor binding activity due to its specificity to $\mathrm{N}$-acetyl or $\mathrm{N}$-glycolyl cell surface oligosaccharides, density of these cellular receptors and level of negative charges on the cell surface may possibly explain these results, showing influence on the sialidase activity and the fusogenic process. Comparative analysis showed a lack of dependence between the sialidase and fusion activities developed by influenza B viruses. Influenza A viruses at low sialidase titers (<2) also exhibited clearly low hemolysis at pH 5.5 (15.8\%), while influenza B viruses with similarly low sialidase titers showed highly variable hemolysis indexes ( 0.2 to $78.0 \%)$. These results support the idea that different virus and cell-associated factors such as those presented above have a significant effect on the multifactorial fusion process.
\end{abstract}

\section{Introduction}

Seven or eight different proteins expressing diverse functions during the replication cycle are coded by segmented RNA of influenza A, B and C viruses. Some of the viruscoded structural proteins form capsids showing helicoidal symmetry and glycoprotein
Key words

- Influenza A, B and C

- Receptor binding activity

- Sialidase activity

- Fusion activity

- Sialic acids

- Cell surface charges spikes responsible for receptor binding,

The envelopes of influenza A and B viruses present surface glycoprotein spikes such as trimeric HA (hemagglutinin) and tetrameric NA (neuraminidase) structures, which show receptor binding/fusion and sialidase activities, respectively, while influsialidase and fusion activities $(1,2)$. 
enza $\mathrm{C}$ virus exhibits only hemagglutininesterase-fusion (HEF) protein trimeric spikes as virus-specified surface structures. HEF structures are responsible for receptor binding, $O$-acetyl esterase and fusion biological activities (1-3). Both HA and HEF structures are only able to expose their fusogenic activity when cleaved by cellular proteases in $\mathrm{HA}_{1} / \mathrm{HA}_{2}$ and $\mathrm{HEF}_{1} / \mathrm{HEF}_{2}$, respectively $(1,2,4)$.

The virus-cell fusion process has been studied at low $\mathrm{pH}$ in spectrophotometric or spectrofluorimetric assays using liposomes or erythrocytes as target membranes (5-8). Virus membranes are deformed and hemagglutinins assume different conformational changes when submitted to acid $\mathrm{pH}$ values such as those used in these assays $(9,10)$. Qualitative and quantitative studies of the contents of gangliosides and sialic acid-containing oligosaccharides composing the cell membranes of diverse animal species have shown different levels of sialic acid-lipid-dependent surface negative charges $(6,10-12)$.

Different strains of influenza A (13), B (14) and $C(5,15,16)$ viruses have demonstrated different standards of behavior when analyzed by hemolysis assay on erythrocytes from some animals used as targets. Hemolysis experiments have been developed using erythrocytes from different animals exposed to the fusogenic activity expressed by different strains of influenza viruses. Neuraminidase activity has also been shown to affect the fusion process of influenza A virus strains, while the same behavior has not been observed in influenza B viruses $(17,18)$.

The objective of the present study was to carry out a comparative study of the role of fusogenic structures of influenza A, B and C virus strains during the hemolysis process expressed on erythrocyte membranes from different animals with different lipid and sialyloligosaccharide compositions and negative charges, as demonstrated by others. The role of influenza A and B virus neuraminidases in the fusogenic process was investi- gated comparatively using erythrocytes from different animals. We also studied the variation in percent hemolysis by strains of influenza A viruses which have receptor binding activity for different cell receptors.

\section{Material and Methods}

\section{Virus strains}

Strains of influenza A virus (A/Aichi/2/ 68, strain X-31), B virus (B/Hong Kong/8/ 73), $\mathrm{C}$ virus (C/Taylor/1233/76), M1/5 and M1/5HS-8 receptor variants of influenza A/ Memphis/102/72 virus were prepared by inoculating the virus preparations into the allantoic cavity of 7- to 9-day-old embryonated eggs. These strains were gifts of Dr. A. Helenius, Department of Cell Biology, Yale University School of Medicine, USA (influenza A viruses, strain X-31), Dr. A. Douglas, National Institute for Medical Research, England (influenza B and C virus strains) and Dr. J.C. Paulson, Cytel Corporation and Department of Chemistry and Molecular Biology, Scripps Research Institute, USA (M1/5 and M1/5HS8 variants of influenza A viruses). The eggs were incubated for 48-72 $\mathrm{h}$ at $34^{\circ} \mathrm{C}$ and the allantoic fluids were harvested and clarified at 7,500 $\mathrm{g}$ for $30 \mathrm{~min}$ at $4^{\circ} \mathrm{C}$. All virus strains were concentrated 50 fold by ultracentrifugation at $80,000 \mathrm{~g}$ for 60 min and purified in a continuous sucrose gradient at $100,000 \mathrm{~g}$ for $120 \mathrm{~min}$ at $4^{\circ} \mathrm{C}$. The virus bands obtained were collected, diluted five times in TVC $(10 \mu \mathrm{M}$ Tris- $\mathrm{HCl}, 10 \mu \mathrm{M}$ versene, $0.10 \mathrm{M}$ sodium chloride, $6 \mu \mathrm{M}$ cysteine) and again pelleted by centrifugation at $80,000 \mathrm{~g}$ for $60 \mathrm{~min}$ at $4^{\circ} \mathrm{C}$. The final pellets were evaluated for protein content by the method of Lowry et al. (19) using bovine albumin as standard and stored at $-20^{\circ} \mathrm{C}(20)$.

\section{Erythrocytes}

Human "O" group $\left(\mathrm{Rh}^{+}\right)$, rabbit, chicken, monkey and horse erythrocytes were used 
after collection in Alsever solution and storage at $4{ }^{\circ} \mathrm{C}$. The cells were adjusted to $1 \%$ or $2 \%$ concentration in appropriate buffers for each test (9) and analyzed in triplicate.

\section{Hemagglutination assay for preliminary standardization of all virus strains}

Twenty-five $\mu l$ of virus strains was diluted serially in equal volumes of $\mathrm{pH} 7.0$ acetate buffer $(0.154 \mathrm{M} \mathrm{NaCl}, 50 \mathrm{mM}$ sodium acetate), with the addition of $25 \mu \mathrm{l}$ of $2 \%$ human erythrocyte suspensions to each virus dilution. The titer (hemagglutination unit, HAU) of each assay developed in triplicate at $4^{\circ} \mathrm{C}$ was considered to be the reciprocal of the highest virus dilution responsible for complete hemagglutination after 60 min incubation (9). All virus strains were then standardized at 1,024 HAU/25 $\mu \mathrm{l}$ with human erythrocytes.

\section{Neuraminidase-lectin assay for analysis of sialidase activity}

Twenty-five $\mu$ of each virus strain standardized at 1,024 HAU was diluted serially from 1:2 to 1:4,096 in equal volumes of 0.15 $\mathrm{M} \mathrm{NaCl}, \mathrm{pH} 7.2$, with the addition of $25 \mu \mathrm{l}$ of $2 \%$ (mammalian) or $1 \%$ (chicken) erythrocyte suspensions to each virus dilution. These erythrocyte suspensions were adjusted to $\mathrm{pH}$ 6.8 using acetate buffer $(0.154 \mathrm{M} \mathrm{NaCl}, 50$ $\mathrm{mM}$ sodium acetate). The microtechnique reactions were incubated at $37^{\circ} \mathrm{C}$ for 120 min or until complete reversal of the initial positive hemagglutination, with later addition of 5 HAU of lectin (PNA) and final homogenization. The titer of sialidase activity was considered to be the reciprocal of the highest dilution of virus strain responsible for complete hemagglutination by PNA after $60 \mathrm{~min}$ of incubation at $25^{\circ} \mathrm{C}(9)$.

\section{Hemolysis assay for analysis of fusion activity}

The fusion activity of the strains was analyzed at different $\mathrm{pH}$ values $(5.5,6.0$, 7.0 ) in a total volume of $3.0 \mathrm{ml}$. Equal volumes $(1.0 \mathrm{ml})$ of $1 / 10$ dilution of each strain standardized at $1,024 \mathrm{HAU} / 25 \mu \mathrm{l}$ and chicken $(1 \%)$ or mammalian (2\%) erythrocyte suspensions were mixed and incubated at $0^{\circ} \mathrm{C}$ on an ice bath for $20 \mathrm{~min}$. These erythrocyte suspensions were adjusted to $\mathrm{pH}$ values of 5.5, 6.0 and 7.0 using acetate buffer $(0.154$ $\mathrm{M} \mathrm{NaCl}, 50 \mathrm{mM}$ sodium acetate). The tubes were incubated at $37^{\circ} \mathrm{C}$ for $60 \mathrm{~min}$ and centrifuged at $600 \mathrm{~g}$ for $10 \mathrm{~min}$. The amount of hemoglobin released in the supernatant by virus-cell fusion-induced hemolysis was measured at $545 \mathrm{~nm}$, while maximal and residual hemolysis were also evaluated by mixing $1.0 \mathrm{ml}$ buffer solution and $1.0 \mathrm{ml}$ erythrocyte suspensions with or without $0.1 \%$ Nonidet P-40, respectively $(6,9)$.

\section{Results and Discussion}

\author{
Analysis of samples of influenza A, B and C \\ viruses for fusogenic activity on human, \\ chicken, rabbit, monkey and horse \\ erythrocytes
}

Different extents of hemolysis were observed when influenza $\mathrm{A}, \mathrm{B}$ and $\mathrm{C}$ viruses were studied for fusogenic activity (Figure 1) on human, chicken, rabbit, monkey and horse erythrocytes. The highest extent of hemolysis was detected at the most acid $\mathrm{pH}$ (5.5), in agreement with some reports $(1,7,21)$, although influenza A, B and C viruses have shown different hemolysis activity at this $\mathrm{pH}$ value (Figure 1). Hemolysis experiments developed at higher $\mathrm{pH}$ values (6.0 and 7.0) showed very little hemolysis (Figure 1, Tables 1 and 2), as already demonstrated (1,7,21). Influenza A and C viruses exhibited important fusion indexes when analyzed for hemolytic activity on erythrocytes of all origins (Figure 1), while influenza B virus showed significant levels of hemolysis only when human erythrocytes were used. All strains showed nonsignifi- 
Figure 1 - Hemolytic activity of influenza viruses as a function of $\mathrm{pH}$. The extent of hemolysis indicates the fusion activity of the viruses on human, chicken, rabbit, monkey and horse erythrocytes. Hemolysis was measured by absorbance at $545 \mathrm{~nm}$, corresponding to the amount of hemoglobin released into the supernatant $(6,9)$. All virus preparations were previously standardized at 1,024 HAU/25 $\mu$ l. Acetate buffers were used. Lozenges, Influenza A/Aichi/2/68; squares, influenza B/Hong Kong/8/73; triangles, influenza $\mathrm{C} /$ Taylor/1233/ 76.

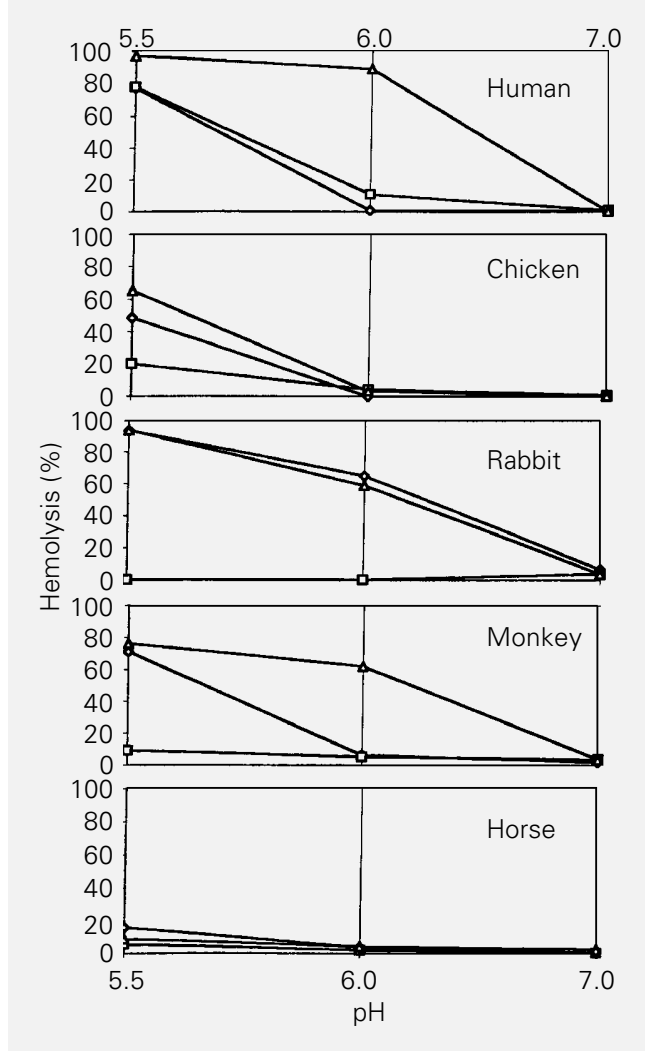

cant hemolysis patterns when horse erythrocytes were used as target cells, as observed in Figure 1.

The results demonstrate that structural diversity of the HA and HEF hemagglutinating spikes of influenza $A, B$ and $C$ viruses is important to determine differences in their biological fusion activity when their fusogenic peptides are exposed to $\mathrm{pH}$ 5.5. These differences have already been demonstrated for different strains of influenza A or B viruses $(6,7,18)$. However, different hemolysis curves were observed in the present study for influenza A, B and C virus strains (Figure 1). Figure 1 shows hemolysis percentages for influenza $\mathrm{A}, \mathrm{B}$ and $\mathrm{C}$ viruses ranging from $77.4 \%$ to $97.2 \%$, from $20.0 \%$ to $65.0 \%$, from $0.2 \%$ to $93.7 \%$ and from $9.0 \%$ to $76.1 \%$, when human, chicken, rabbit and monkey cells were tested at $\mathrm{pH} 5.5$, respectively.

Low hemolysis indexes for influenza $\mathrm{A}$ (15.8\%), B (5.5\%) and C (8.7\%) viruses at
pH 5.5 were observed when horse erythrocytes were used as target cells for the fusion process (Figure 1), which can be explained by inefficient virus receptor binding activity on N-glycolyl sialic acids. These glycolyl sialic acids are present in higher percentages in horse cells (95\%) when compared to Nacetyl sialic acids (5\%), which are observed at higher levels (95\%) in sialic acid-containing structures of human, chicken, rabbit and monkey cells (11). This lower hemolytic activity detected for all strains of influenza virus on horse cells may be explained by very low levels of surface negative charges due to the presence of sialic acids or gangliosides $(11,22)$. The type and diversity of sialic acids of cell surfaces and the virus receptor binding activity on these structures have a direct influence during the fusion process $(8,16,20,22)$.

\section{Analysis of strains of influenza A and B viruses for interdependence of sialidase and fusogenic activities}

The interdependence of cleaving activity of neuraminidase, receptor binding activity of hemagglutinin and hemolytic activity of hemagglutinin fusion peptide may possibly explain the nonsignificant receptor binding or cleavage of $\mathrm{N}$-glycolyl-containing receptor structures reported above. Actually, the cleaving activity of neuraminidase on hemagglutinins already bound to cell receptors permits a $35-70^{\circ}$ tilt from the normal membrane $(23,24)$, conformational changes and the insertion of their hemagglutinin fusion peptides into cell membranes (25), resulting in the final fusion process (26). The lower level of cell surface charges per horse erythrocyte when compared to human and chicken cells may be another possible explanation for these results.

Comparative analysis of influenza A and $B$ virus strains showed the absence of dependence between sialidase and fusion activities for influenza B virus (Table 1), and 
significantly different hemolysis percentages associated with almost similar neuraminidase titers as observed previously $(17,18)$. At $\mathrm{pH}$ 5.5, influenza A virus exhibited clearly lower hemolysis percentages $(15.8 \%)$ in the presence of low titers of sialidase activity $(<2)$, while very variable hemolysis indexes for influenza B viruses $(0.2 \%$ to $77.8 \%)$ were observed for similar sialidase titers (from 128 to 256).

\section{Analysis of variant strains of influenza $A$ viruses selected for their receptor specificity for $\mathrm{N}$-glycolyl-containing oligosaccharides demonstrating the interdependence among hemagglutinin receptor specificity and sialidase/fusion activities}

Variable hemolysis of horse erythrocytes could be observed when M1/5 and M1/5HS8 variant strains of influenza A were analyzed (Table 2). M1/5HS 8 variant strain which was selected by adsorption of native virus preparations (M1/5) on substrate rich in $\mathrm{N}$ glycolyl-containing receptor residues (horse serum) induced a significant sialidase titer (1024) and low percentage of horse cell hemolysis at $\mathrm{pH}$ 5.5. However, M15 variant strain exhibited a lower sialidase titer (64) and a higher hemolysis (83.0\%), while nonsignificant differences were observed when human, chicken, rabbit and monkey cells were used. These results could be explained by the selection of an escape variant strain (M1/5HS8) containing virus subpopulations with probably different fusogenic sequences in the hemagglutinin amino acid chain (25), without affinity for $\mathrm{N}$-glycolyl-containing structures present at high percentage in horse cells. Indeed, clear diversity of virus samples in terms of receptor binding activity to $\mathrm{N}$ glycolyl sialic acid residues has been previously reported $(21,26)$.

This study demonstrates some unknown or still unexplored aspects of fusogenic activity, in an attempt to confirm the existence of multiple factors related to fusion activity.
Table 1 - Comparison of sialidase and fusion activities of influenza $A$ and $B$ viruses on erythrocytes from different sources.

Sialidase activity was measured in a neuraminidase-lectin assay and is reported as the reciprocal of the highest virus dilution causing complete hemagglutination by PNA. Fusogenic activity was measured by hemolysis and activity is reported as percent hemolysis measured at $545 \mathrm{~nm}$. All virus strains were previously standardized at 1,024 $\mathrm{HAU} / 25 \mu \mathrm{l}$.

\begin{tabular}{|c|c|c|c|c|c|c|}
\hline \multirow[t]{3}{*}{ Erythrocytes } & \multicolumn{3}{|c|}{$\begin{array}{l}\text { Influenza A/Aichi/2/68 } \\
\text { clonal variant X-31 }\end{array}$} & \multicolumn{3}{|c|}{ Influenza B/Hong Kong/8/73 } \\
\hline & \multirow{2}{*}{$\begin{array}{l}\text { Sialidase } \\
\text { activity }\end{array}$} & \multicolumn{2}{|c|}{ Fusion activity } & \multirow{2}{*}{$\begin{array}{l}\text { Sialidase } \\
\text { activity }\end{array}$} & \multicolumn{2}{|c|}{ Fusion activity } \\
\hline & & pH 5.5 & $\mathrm{pH} 6.0$ & & $\mathrm{pH} 5.5$ & $\mathrm{pH} 6.0$ \\
\hline Human & 1024 & 77.4 & 0.7 & 256 & 77.8 & 11.0 \\
\hline Chicken & 256 & 48.7 & 16.4 & 256 & 20.0 & 4.3 \\
\hline Rabbit & 256 & 93.2 & 65.6 & 128 & 0.2 & 0.2 \\
\hline Monkey & 256 & 71.5 & 6.1 & 256 & 8.9 & 4.9 \\
\hline Horse & $<2$ & 15.8 & 3.6 & 256 & 5.5 & 1.2 \\
\hline
\end{tabular}

Table 2 - Sialidase and fusion activities of influenza A/Memphis/102/72 (M1/5) virus and a receptor binding variant $(\mathrm{M} 1 / 5 \mathrm{HS} 8)$ derived from it.

The mutant was obtained from $\mathrm{M} 1 / 5$ by replication in the presence of $1 \%$ horse serum, which contains $95 \%$ of its sialic acid residues in the N-glycolyl form. Sialidase activity was measured in a neuraminidase-lectin assay and is reported as the reciprocal of the highest virus dilution causing complete hemagglutination by PNA. Fusogenic activity was measured by hemolysis and activity is reported as percent hemolysis measured at $545 \mathrm{~nm}$. All virus strains were previously standardized at 1,024 HAU/25 $\mu$ l.

\begin{tabular}{|c|c|c|c|c|c|c|}
\hline \multirow[t]{3}{*}{ Erythrocytes } & \multicolumn{3}{|c|}{$\mathrm{M} 1 / 5$} & \multicolumn{3}{|c|}{ M1/5HS8 } \\
\hline & \multirow{2}{*}{$\begin{array}{c}\text { Sialidase } \\
\text { activity }\end{array}$} & \multicolumn{2}{|c|}{ Fusion activity } & \multirow{2}{*}{$\begin{array}{l}\text { Sialidase } \\
\text { activity }\end{array}$} & \multicolumn{2}{|c|}{ Fusion activity } \\
\hline & & $\mathrm{pH} 5.5$ & $\mathrm{pH} 6.0$ & & $\mathrm{pH} 5.5$ & $\mathrm{pH} 6.0$ \\
\hline Human & 256 & 97.2 & 95.1 & 512 & 97.1 & 1.4 \\
\hline Chicken & 4096 & 55.6 & 50.5 & 512 & 60.8 & 4.6 \\
\hline Rabbit & 256 & 97.3 & 98.2 & 512 & 95.6 & 9.7 \\
\hline Monkey & 256 & 91.2 & 61.7 & 512 & 79.2 & 70.3 \\
\hline Horse & 64 & 83.0 & 13.7 & 1024 & 3.5 & 4.7 \\
\hline
\end{tabular}

HA and HEF surface structures of influenza $\mathrm{A}, \mathrm{B}$ and $\mathrm{C}$ were shown to act differently on cell surface membranes, which exhibited different compositions in terms of sialic acidcontaining structures and surface electron charges. The evidence obtained indicates that many parameters must be considered for chemical, functional and structural studies on virus hemagglutinins and cell membranes. The present results support the idea that 


\author{
different virus and cell-associated factors \\ have a significative effect on the fusogenic \\ process of hemagglutinins, representing a \\ multifactorial process.
}

\section{Acknowledgments}

\author{
We thank Maria Alves Teixeira for tech- \\ nical assistance and Elizabeth Brito Ferrarezzi \\ for secretarial help.
}

\section{References}

1. Formanowski F, Wharton SA, Calder LJ, Hofbauer C \& Meier-Ewert H (1990). Fusion characteristics of influenza $C$ viruses. Journal of General Virology, 71: 11811188.

2. Higa HH, Rogers GN \& Paulson JC (1985). Influenza virus hemagglutinins differentiate between receptor determinants bearing N-acetyl-, N-glycolyl- and N,Odiacetylneuraminic acids. Virology, 144: 279-282.

3. Herrler G \& Klenk H (1991). Structure and function of the HEF glycoprotein of influenza C virus. Advances in Virus Research, 40: 213-233.

4. Herrler G \& Klenk H (1987). The surface receptor is a major determinant of the tropism of influenza C virus. Virology, 159: 102-108.

5. Gaudin $Y$, Ruigrok RWH \& Brunner J (1995). Low-pH induced conformational changes in viral fusion proteins: implications for the fusion mechanism. Journal of General Virology, 76: 1541-1556.

6. Huang RTC, Rott R, Whan K, Klenk HD \& Kohama T (1980). The function of the neuraminidase in membrane fusion induced by Myxoviruses. Virology, 107: 313319.

7. Lenard J, Bailey CA \& Miller DK (1982). $\mathrm{pH}$ dependence of influenza $A$ virus-induced haemolysis is determined by the haemagglutinin gene. Journal of General Virology, 62: 353-355.

8. Suzuki $Y$, Nagao $Y$, Kato $H$, Matsumoto M, Nerome K, Nakajima K \& Nobusawa E (1986). Human influenza A hemagglutinin distinguishes sialyloligosaccharides in membrane-associated gangliosides as its receptor which mediates the adsorption and fusion processes of virus infection. Journal of Biological Chemistry, 261: 17057-17061.

9. Pinto AMV, Cabral MC \& Couceiro JNSS (1994). Parainfluenza virus type 1 variants: analysis of hemagglutinating, neuraminidase and fusion activities. Revista de Microbiologia, 25: 175-180.
10. Reuter G, Stoll S, Kamerling JP Vliegenthart JFG \& Schauer R (1988). Sialic acids on erythrocytes and in blood plasma of mammals. In: Schauer R \& Yamakawa T (Editors), Proceedings of the Japanese-German Symposium on Sialic Acids. Japanisch-Deutsches Zentrum, Berlin, 88-89.

11. Eylar EH, Madoff MA, Brody OV \& Oncley JL (1962). The contribution of sialic acid to the surface charge of the erythrocyte. Journal of Biological Chemistry, 237: 1992-2000.

12. Winzler RJ (1969). A glycoprotein in human erythrocyte membranes. In: Jamieson GA \& Greenwalt TJ (Editors), Red Cell Membrane and Function. Lippincott-Raven Publishers, Philadelphia, 157-171.

13. Clark E \& Nagler FPO (1943). Haemagglutination by viruses. The range of susceptible cells with special reference to agglutination by vaccinia virus. Australian Journal of Experimental Biology and Medical Science, 21: 103-106.

14. Ruigrok RWH, Hewat EA \& Wade EH (1992). Low pH deforms the influenza virus envelope. Journal of General Virology, 73: 995-998.

15. Minuse E, Quilligan Jr JJ, Francis TF \& Mich AA (1954). Type C influenza virus. I. Studies of the virus and its distribution. Journal of Laboratory and Clinical Medicine, 43: 31-42.

16. Ohuchi M, Ohuchi R \& Mifune K (1982). Demonstration of hemolytic and fusion activities of influenza $C$ virus. Journal of Virology, 42: 1076-1079

17. Lamb RA \& Krug RM (1995). Orthomyxoviridae: The viruses and their replication. In: Fields BN, Knipe DM \& Hewley PM (Editors), Virology. Lippincott-Raven Publishers, Philadelphia, 1353-1395.

18. Shibata M, Maeno K, Tsurumi T, Aoki H, Nishiyama $Y$, Ito $Y$, Isomura $S$ \& Suzuki $S$ (1982). Role of viral glycoproteins in haemolysis by influenza B virus. Journal of General Virology, 59: 183-186.
19. Lowry $\mathrm{OH}$, Rosebrough NJ, Farr $\mathrm{AL}$ \& Randall RJ (1951). Protein measurement with the Folin phenol reagent. Journal of Biological Chemistry, 193: 265-273.

20. Pinto AMV, Cabral MC \& Couceiro JNSS (1994). Hemagglutinating and sialidase activities of subpopulations of influenza A viruses. Brazilian Journal of Medical and Biological Research, 27: 1141-1147.

21. Huang RTC, Rott R \& Klenk HD (1981). Influenza viruses cause hemolysis and fusion of cells. Virology, 110: 243-247.

22. Stegmann T, Hoekstra D, Scherphof G \& Wilschut $J$ (1986). Fusion activity of influenza virus. A comparison between biological and artificial target membrane vesicles. Journal of Biological Chemistry, 261: 10966-10969.

23. Tatulian SA, Hinterdorfer P, Baber G \& Tamm LK (1995). Influenza hemagglutinin assumes a tilted conformation during membrane fusion as determined by attenuated total reflection FTIR spectroscopy. EMBO Journal, 14: 5514-5523.

24. Puri A, Booy FP, Doms RW, White JM \& Blumenthal R (1990). Conformational changes and fusion activity of influenza virus hemagglutinin of the $\mathrm{H} 2$ and $\mathrm{H} 3$ subtypes: effects of acid treatment. Journal of Virology, 64: 3824-3832.

25. Steinhauer DA, Wharton SA, Skehel JJ \& Wiley DC (1995). Studies of the membrane fusion activities of fusion peptide mutants of influenza virus hemagglutinin. Journal of Virology, 69: 6643-6651.

26. Suzuki $Y$, Nagao $Y$, Kato $H$, Suzuki T, Matsumoto M \& Murayama J (1987). The hemagglutinins of the human influenza $A$ and $B$ recognize different receptor microdomains. Biochimica et Biophysica Acta, 903: 417-424. 